\title{
DEVELOPMENT OF LOCAL ALLOMETRIC EQUATION TO ESTIMATE TOTAL ABOVEGROUND BIOMASS IN PAPUA TROPICAL FOREST
}

\author{
Sandhi I.Maulana ${ }^{1 *}$, Yohannes Wibisono ${ }^{1}$ and Singgih Utomo ${ }^{2}$ \\ ${ }^{1}$ Manokwari Environment and Forestry Research and Development Institute, \\ Jl. Inamberi-Susweni, Manokwari 98313-Papua Barat, Indonesia \\ ${ }^{2}$ Forest Management Program, Vocational College of Gadjah Mada University, Yogyakarta, Indonesia
}

Received: 3 February 2015, Revised: 29 September 2016, Accepted: 21 October 2016

\begin{abstract}
DEVELOPMENT OF LOCAL ALLOMETRIC EQUATION TO ESTIMATE TOTAL ABOVEGROUND BIOMASS IN PAPUA TROPICAL FOREST. Recently, pantropical allometric equations have been commonly used across the globe to estimate the aboveground biomass of the forests, including in Indonesia. However, in relation to regional differences in diameter, height and wood density, the lack of data measured, particularly from eastern part of Indonesia, may raise the question on accuracy of pantropical allometric in such area. Hence, this paper examines the differences of local allometric equations of Papua Island with equations developed by Chave and his research groups. Measurements of biomass in this study were conducted directly based on weighing and destructive samplings. Results show that the most appropriate local equation to estimate total aboveground biomass in Papua tropical forest is $\log (T A G B)=$ $-0.267+2.23 \log (D B H)+0.649 \log (W D)\left(C F=1.013 ; V I F=1.6 ; R^{2}=95 \% ; R^{2}\right.$-adj $=95.1 \% ; R M S E=0.149 ;$ $P<0.001)$. This equation is also a better option in comparison to those of previously published pantropical equations with only $6.47 \%$ average deviation and 5.37 points of relative bias. This finding implies that the locally developed equation should be a better option to produce more accurate site specific total aboveground biomass estimation.
\end{abstract}

Keywords: Pantropical, local, allometric, biomass, Papua

PENYUSUNAN PERS AMAAN ALOMETRIK LOKAL UNTUKMENDUGA BIOMASSA TOTAL DI ATAS PERMUKAAN TANAH DI KAWASAN HUTAN TROPIS PAPUA. Saat ini, persamaan alometrik pantropis telah umum digunakan untuk. mendapatkan nilai dugaan biomassa di atas permukaan tanah di kawasan butan, termasuk di Indonesia. Namun sebubungan dengan adanya perbedaan dalam karakteristik diameter, tinggi, dan berat jenis pohon, kurangnya pengukuran data, khususnya di daerah timur Indonesia menyebabkan adanya keraguan terkait besarnya simpangan dan bias yang dihasilkan oleh penggunaan persamaan pantropis di daerah tersebut. Oleh karena itu, tulisan ini mempelajari perbandingan persamaan alometrik yang dibangun secara spesifik terhadap lokasi dan persamaaan alometrik pantropis yang telah dipublikasikan oleh Chave dan kelompok penelitinya. Pendugaan biomassa pada penelitian ini dilaksanakan berdasarkan pengukuran dan penimbangan secara langsung secara destruktif. Hasil penelitian menunjuk.kan babwa persamaan lokal yang sesuai untuk pendugaan nilai biomassa di atas permukaan tanah di kawasan butan tropis Papua adalah $\log (\mathrm{TAGB})=-0,267+2,23 \log (\mathrm{DBH})+0,649 \log (\mathrm{WD})\left(\mathrm{CF}=1,013 ; \mathrm{VIF}=1,6 ; \mathrm{R}^{2}=95 \%\right.$; $\mathrm{R}^{2}$-adj= 95,1\%; $\left.\mathrm{RMSE}=0,149 ; \mathrm{P}<0,001\right)$. Apabila dibandingkan dengan persamaan alometrik pantropis yang telah dipublikasikan sebelumnya, persamaan lokal tersebut menghasilkan nilai dugaan yang lebih baik dengan nilai simpangan rata-rata hanya 6,47\% dan nilai bias relatif sebesar 5,37. Hasil ini mengindikasikan bahwa persamaan alometrik yang dibangun secara lokal sebaiknya dijadikan sebagai pertimbangan utama untuk mendapatkan nilai dugaan total biomassa di atas permukaan tanah yang lebih akurat.

Kata kunci: Pantropis, lokal, alometrik, biomassa, Papua

*Corresponding author: frost_stick@yahoo.com 


\section{INTRODUCTION}

Along with the progress of reducing emission from deforestation and forest degradation (REDD+) in Indonesia and the high possibility of benefits that might be achieved from conservation of forest carbon stocks, a verifiable and precise estimation of carbon stocks in the country's forestry sector is strongly needed. Estimating forest carbon stocks relies on certain approaches depending on the scales, starting from field weighing at local level to the application of geographical information system (GIS) at national level. However, all these approaches still rely on biomass measurement of the trees. (Clark \& Kellner, 2012; Jaya et al., 2012; Achmad, Jaya, Saleh, \& Kuncahyo, 2013). Nowadays, there is a risk of environmental deterioration as a result from direct biomass measurements, combined with the cost of such destructive approach that tends to be very high. The alternative that has been generally used is an allometric equation (Lewis et al., 2013; Ngomanda et al., 2014). In general, allometric equation is a statistical model to estimate the biomass of the trees using their biometrical characteristics, like height or diameter, which are non-destructive and simpler to measure (Eggleston et al., 2006; Maulana, 2014; Ngomanda et al., 2014). Up to now, Chave's pantropical allometric equations are the most commonly used across the globe, including in Indonesia (Lewis et al., 2009; Ngomanda et al., 2014). Nevertheless, in relation to regional differences in diameter, height and wood density, the lack of data measured from eastern part of Indonesia may question the degree of deviation and bias produced from the use of pantropical allometric which were developed by Chave, Andalo, Brown, Cairns, Chambers, Eamus, ... Yamakura (2005) and Chave, Réjou-Méchain, Búrquez, Chidumayo, Colgan, Delitti, ... Vieilledent (2014) in such area as evidenced by Maulana (2014).

Furthermore, debates over the application of Chave's pantropical allometric are continuing since several regional studies have came out with different results. A study by Fayolle et al.
(2013) reported that pantropical equation is strongly justifiable to estimate the biomass of south-eastern Cameroon forests. Similar finding had also been contended by Vieilledent et al. (2012) for its validity over biomass estimation in Madagascar. In contrast, several studies also described that the use of Chave's pantropical equations might result in significant bias, as reported by Henry et al. (2010) in Ghana, Lima et al. (2012) in Amazonia, by Alvarez et al. (2012) in Columbia.

Hence, in order to answer the dilemma between the use of pantropical and locally developed equations, this paper studies the differences of local allometric equations for Papua Island with equations developed by Chave et al. (2005) and an improved pantropical allometric equation by Chave et al. (2014). Thus, the main objective of this study is to develop an improved allometric equation for mixed species in Papua Island. Considering this objective, this study produced local allometric equations for mixed species across Papua Island as an improvement to previously published equations by Maulana (2014) using new data that includes four additional genus, namely Anthocephalus, Duabanga, Myristica and Syzygium. Afterward, the study evaluated it against both Chave et al. (2005) and Chave et al. (2014) equations using actual (direct measurements) biomass data.

\section{MATERIAL AND METHOD}

\section{A. Study Site}

As depicted in Table 1 and Figure 1, this study was conducted at six regencies across Papua Island. Table 1 also contains the number of trees felled in this study, which were 83 , with $\mathrm{dbh}$ (diameter at breast height $/ 1.3 \mathrm{~m}$ ) ranging from 5 to $48.5 \mathrm{~cm}$, and consist of eight genera.

\section{B. Biomass Measurement}

Concisely illustrated in Figure 2, a set of proper and prudence procedure has been adopted to obtain reliable data and minimize any source of bias. To the extent of greater accuracy, as advised by Basuki et al. (2009), measurements of biomass in this study were 
Table 1. Study area, coordinates and number of trees felled per genera

\begin{tabular}{|c|c|c|c|c|}
\hline Site & Location & Genera & Coordinates & $\begin{array}{l}\text { Number of } \\
\text { trees felled }\end{array}$ \\
\hline 1 & Sorong & Anthocephalus & $\begin{array}{l}0^{\circ} 33^{\prime} 42^{\prime \prime}-1^{\circ} 35^{\prime} 29^{\prime \prime} \mathrm{S} \\
30^{\circ} 40^{\prime} 49^{\prime \prime}-132^{\circ} 33^{\prime} 48^{\prime \prime} \mathrm{E}\end{array}$ & 8 \\
\hline 2 & Mamberamo & Duabanga & $\begin{array}{l}01^{\circ} 28-3^{\circ} 50 \mathrm{~S} \\
137^{\circ} 46-140^{\circ} 19 \mathrm{E}\end{array}$ & 8 \\
\hline 3 & Fak-fak & Intsia & $\begin{array}{l}2^{\circ} 25^{\prime} 0^{\prime \prime}-4^{\circ} 0^{\prime} 0^{\prime \prime} \mathrm{S} \\
131^{\circ} 30^{\prime} 0^{\prime \prime}-138^{\circ} 40^{\prime} 0^{\prime \prime} \mathrm{E}\end{array}$ & 13 \\
\hline 4 & Bintuni & $\begin{array}{l}\text { Myristica } \\
\text { Palaquium } \\
\text { Syzygium }\end{array}$ & $\begin{array}{l}1^{\circ} 57^{\prime} 50^{\prime \prime}-3^{\circ} 11^{\prime} 26^{\prime \prime} \mathrm{S} \\
132^{\circ} 44^{\prime} 59^{\prime \prime}-134^{\circ} 14^{\prime} 49^{\prime \prime} \mathrm{E}\end{array}$ & $\begin{array}{r}9 \\
13 \\
9\end{array}$ \\
\hline 5 & Keerom & Pometia & $\begin{array}{l}140^{\circ} 15^{\prime} 0^{\prime \prime}-141^{\circ} 0^{\prime} 0^{\prime \prime} \mathrm{S} \\
2^{\circ} 37^{\prime} 0^{\prime \prime}-4^{\circ} 0^{\prime} 0^{\prime \prime} \mathrm{E}\end{array}$ & 15 \\
\hline 6 & Raja Ampat & Vatica & $\begin{array}{l}0^{\circ} 10^{\prime} \mathrm{S}-0^{\circ} 20^{\prime} \mathrm{N} \\
130^{\circ} 0^{\prime} \mathrm{W}-132^{\circ} 0^{\prime} 55^{\prime \prime} \mathrm{E}\end{array}$ & 8 \\
\hline \multicolumn{4}{|c|}{ Total number of trees felled } & 83 \\
\hline
\end{tabular}

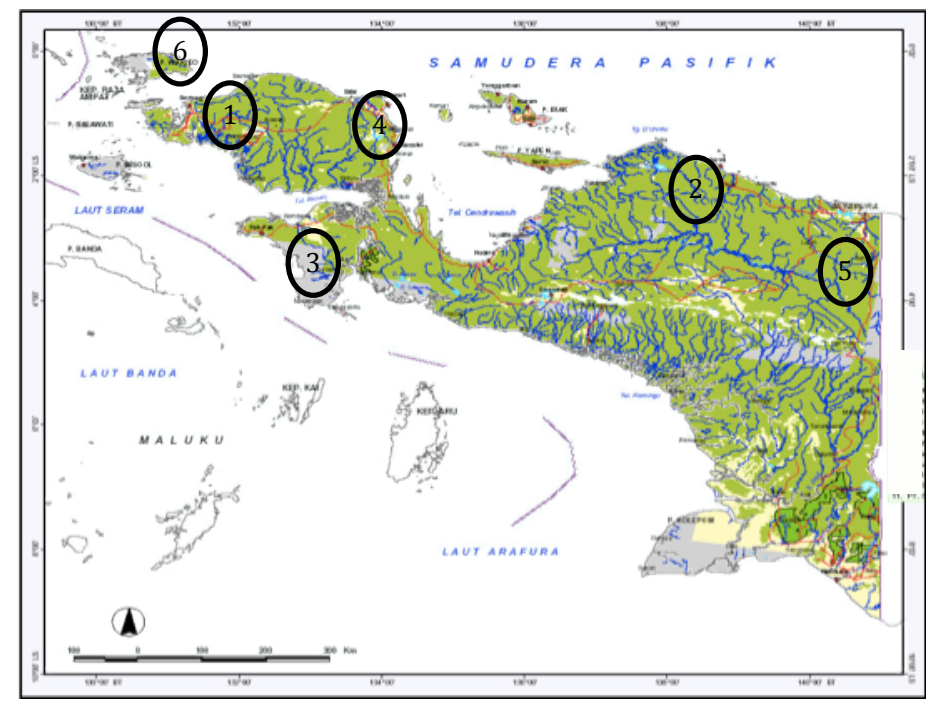

Figure 1. Study site map

Source: FWI (2004)

conducted directly based on weighing and destructive samplings. The dry biomass of the material of a pool of tree was measured using the aliquot approach, which is a piece of sample with a known mass as a fraction of the whole pool of the material. Based on this approach, dry biomass of a pool of material equals to the fresh biomass of the pool of the material divided by the fresh biomass of its aliquot times the dry biomass of the aliquot. This approach was logical if only the ratio of the dry over fresh biomass was homogeneous for the whole pool. Therefore, as suggested by Ketterings et al. (2001), each tree felled was divided into five pools, namely leaves, twigs (diameter $<3.2 \mathrm{~cm}$ ), small branches (diameter $3.2-6.4 \mathrm{~cm}$ ), large branches (diameter $>6.4 \mathrm{~cm}$ ) and stems.

Each tree was felled so that its crown fell on the most open ground possible in its area, which limited the destruction of its foliage to the lowest possible loss. Once a tree was felled, the volume of each section was calculated using 


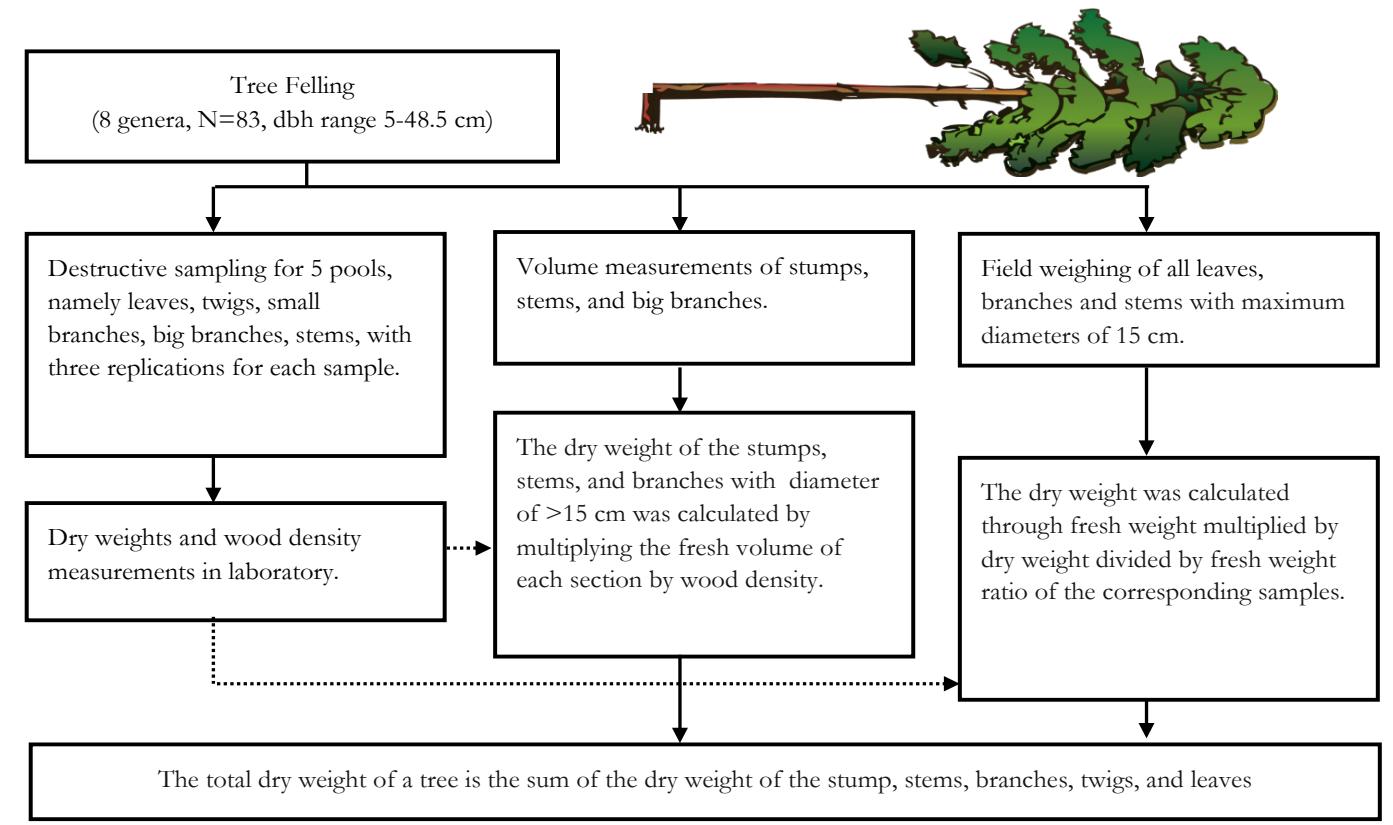

Figure 2. Flow chart of biomass measurement

Smalian's formula as cited by De Gier (2003), so that the total volume is the sum of the volumes of each section. Meanwhile, branches and stems with maximum diameters of $15 \mathrm{~cm}$ were measured directly in the field using hangup balance of $50 \mathrm{~kg}$ capacity with an accuracy of $1 \%$. Moreover, the smaller samples were weighed using a $1000 \mathrm{gr}$ table scale with an accuracy of $0.5 \%$. Three replications were taken for the samples from the partitioned trees and put into sealed plastic bags, and then brought to the laboratory to measure their moisture content. From that point, an analytical balance with maximum capacity of $500 \mathrm{gr}$ and an accuracy of $0.001 \mathrm{gr}$ was utilized to weigh those samples. Dry weights were obtained by drying the samples at $105^{\circ} \mathrm{C}$ temperature until the constant value was obtained (Stewart et al., 1992; Ketterings et al., 2001).

In order to measure the wood density at the laboratory, samples were taken from the lower and upper parts of the main trunk sections with 2 meters interval. To include the inner and outer parts of the trunks with their bark, the samples were taken as a pie shape or cylinder (Nelson et al., 1999). Water replacement method was used in measuring the wood density. The samples were saturated at first to prevent size contraction during volume measurement. This was conducted through 48 hours rehydration. Each sample's volume was obtained from the displaced water volume when submerged. Finally, the wood density was equal to the oven dry weight divided by the saturated volume. The dry weight of the stumps, stems, and branches with diameter of $>15 \mathrm{~cm}$ was calculated by multiplying the fresh volume of each section by wood density. For the other partitioned trees, the dry weight was calculated through fresh weight multiplied by dry weight divided by fresh weight ratio of the corresponding samples. The total dry weight of a tree is the sum of the dry weight of the stump, stem, branches, twigs, and leaves (Stewart et al., 1992).

\section{Allometric Equations}

\section{Analysis of variance}

Based on findings by Maulana (2014), in this study locally developed allometric for mixed species was established using two predictors, namely diameter at breast height $(D B H)$ and wood density $(W D)$. Hence, the equations to estimate total aboveground biomass (TAGB) were established according to the following 
basic models:

$$
\begin{aligned}
& \log (T A G B)=c+\alpha \log (D B H)+\beta \log (W D) \\
& T A G B=c+\alpha D B H+\beta W D^{2} \\
& T A G B=c+\alpha W D+\beta D B H^{2}
\end{aligned}
$$

Subsequently, in order to fulfill the assumptions in the regression establishment, four tests were conducted, namely Variance Influential Factors (VIF) for multicollinearity test, Pearson's correlation coefficient test, normal distribution of residuals test, and test for constant variance of residuals. Allometric model comparison and selection was analyzed using the values of standard error of the coefficient, $R^{2}, R^{2}$ (adj), and root mean square error (RMSE) based on Minitab 14.0 software. The chosen model would be the one with the highest values for $R^{2}$ and $R^{2}$ (adj), while having the lowest values of standard error of the coefficient and RMSE. Additionally, in order to enhance the reliability of the established $\log$ model (Equation 1), a correction factor (CF; Equation 4) for back transforming the model was calculated from the standard error of estimate (SEE; Equation 5) as defined in Sprugel (1983).

$$
C F=\exp \left(\mathrm{SEE}^{2} / 2\right)
$$

$S E E-{\sqrt{\sum\left(\frac{\log Y_{i}-\log \hat{Y}_{i}}{N-2}\right)^{2}}}^{2}$

Where:

$$
\begin{aligned}
\log Y_{i}= & \text { values of dependent variable } \\
\log \hat{Y}_{i}= & \text { corresponding predicted values } \\
& \text { calculated from the equation } \\
N \quad= & \text { total number of observations }
\end{aligned}
$$

Afterwards, using data from actual biomass measurement in Papua Island, the chosen equation in this study was evaluated against Chave et al. (2005) equation, which were Equation 6 and Equation 7, as well as Chave et al. (2014)'s pantropical allometric as depicted in Equation 8. Meanwhile, as suggested by Basuki et al. (2009); Ngomanda et al. (2014) and Tedeschi (2006), criteria for this evaluation included average deviation (Eq. 9) and relative bias (Eq. 10).

$T A G B=W D \exp [-1.499+2.148 \operatorname{Ln}(D B H)$

+ $\left.0.207(\operatorname{Ln}(D B H))^{2}-0.0281(\operatorname{Ln}(D B H))^{3}\right]$

$T A G B=W D \exp [-1.239+1.98 \operatorname{Ln}(D B H)+$ $\left.0.207(\operatorname{Ln}(D B H))^{2}-0.0281(\operatorname{Ln}(D B H))^{3}\right]$

$T A G B=0.0673 \times\left(D B H^{2} \times W D \times H\right)^{0.976}$

$$
\begin{aligned}
& \bar{S}-\frac{10 O}{\eta} \sum_{i=1}^{\eta} \frac{\left|B_{i}-b_{2}\right|}{b_{i}} \\
& R B-\frac{1}{\eta} \sum_{i=1}^{\eta}\left(B_{1}-b_{1}\right) / b_{i}
\end{aligned}
$$

\section{Where:}

$\bar{S}=$ average deviation

$\mathrm{RB}=$ relative bias

$B i=$ actual aboveground biomass for tree- $\mathrm{i}$

$b i=$ its estimation based on the model

$\eta=$ number of observations

\section{RESULT AND DISCUSSION}

\section{A. Local Equation}

Compared to wood density values from published literature, as shown in Table 2 , result of measurements in this study illustrate a highly rational wood density for each genera. However, it should be kept in mind that although samples for wood density measurements originated from both upper and lower parts (with $2 \mathrm{~m}$ interval) of each main trunk, these data were also used to estimate the weight of the material of the trees that were difficult or even impossible to measure, such as big branches. As reported by Basuki et al. (2009), this approach might result in over-estimation in regard to total weight of the tree. Meanwhile, Nogueira et al. (2007) also noted that wood density of a tree tends to be higher at breast height than in the upper part of the bole, and also higher at the bottom of the trunk of the tree than at the living crown's base. Afterwards, following the previously determined model, three local equations were established as listed in Table 3. In this study, multicollinearity test was conducted by harnessing the value of Variance Influential 
Table 2. Result of wood density measurements

\begin{tabular}{|c|c|c|c|c|c|c|c|c|}
\hline \multirow[t]{2}{*}{ Genus } & \multirow{2}{*}{$\begin{array}{l}\text { Number } \\
\text { of trees } \\
(\mathrm{N})\end{array}$} & \multirow{2}{*}{$\begin{array}{l}\text { Number } \\
\text { of wood } \\
\text { density } \\
\text { sample } \\
\text { (n) }\end{array}$} & \multicolumn{2}{|c|}{$\begin{array}{l}\text { Wood density } \\
\text { range } \\
\left(\mathrm{gr} / \mathrm{cm}^{3}\right)\end{array}$} & \multirow{2}{*}{$\begin{array}{l}\text { Average } \\
\left(\mathrm{gr} / \mathrm{cm}^{3}\right)\end{array}$} & \multirow{2}{*}{$\begin{array}{l}\text { Standard } \\
\text { deviation }\end{array}$} & \multirow{2}{*}{$\begin{array}{l}\text { Coefficient } \\
\text { of variation }\end{array}$} & \multirow{2}{*}{$\begin{array}{c}\text { PROSEA } \\
(2007)^{*} \\
\left(\mathrm{gr} / \mathrm{cm}^{3}\right)\end{array}$} \\
\hline & & & $\min$ & $\max$ & & & & \\
\hline Anthocephalus & 8 & 36 & 0.30 & 0.56 & 0.43 & 0.09 & 0.21 & $0.29-0.56$ \\
\hline Duabanga & 8 & 42 & 0.28 & 0.48 & 0.38 & 0.07 & 0.18 & $0.27-0.51$ \\
\hline Intsia & 13 & 92 & 0.43 & 0.86 & 0.64 & 0.15 & 0.23 & $0.50-1.04$ \\
\hline Myristica & 9 & 87 & 0.41 & 0.63 & 0.52 & 0.08 & 0.15 & $0.40-0.65$ \\
\hline Palaquium & 13 & 86 & 0.33 & 0.56 & 0.44 & 0.07 & 0.16 & $0.45-0.51$ \\
\hline Pometia & 15 & 98 & 0.37 & 0.75 & 0.56 & 0.12 & 0.21 & $0.39-0.77$ \\
\hline Sysygium & 9 & 74 & 0.54 & 0.80 & 0.67 & 0.09 & 0.13 & $0.56-0.83$ \\
\hline Vatica & 8 & 44 & 0.54 & 0.67 & 0.60 & 0.05 & 0.08 & $0.60-0.76$ \\
\hline Total & 83 & 559 & - & - & - & - & - & - \\
\hline
\end{tabular}

*published wood density

Factors $(V T F)$. In short, according to Fahrmeir et al. (2013), the aim of such test is to investigate whether there is an indication of high correlation among predictors (input variables, $\mathrm{x})$ or not. Evidently, none of the established models indicated the presence of significant multicollinearity among its predictors, since the VIF value only ranged from 1.4 to 1.6 point. As described by Fahrmeir et al. (2013), this means that there is only a very low degree of correlation among predictors used in the model, and that values of VIF were insufficient to be overly concerned.

Meanwhile, to strengthen the result of the multicollinearity test, analysis of correlation among variables was performed. The first step of this correlation test was to use a graphical approach or scatter plot to explore the appearance of correlation among involved variables (Chaturvedi \& Raghubanshi, 2015). As shown in Figure 3, and in line with the result of multicollinearity test, apparently it is clear that there was no obvious relationship among predictors or input variables, $W D$ and $D B H$. In contrast, both scatter plots for $T A G B$ vs $W D$ and $T A G B$ vs $D B H$, which were basically output vs input variables, demonstrated a direct relationship. The strength of this correlation was further examined using Pearson's coefficient test and the results were depicted in Table 4. Considering the value of Pearson's correlation of coefficient $(r)$ in the table, where $r>0.6$, it seems that $D B H$ and $W D$ were reliable input variables in predicting $T A G B$. This finding is

Table 3. Result of wood density measurements

\begin{tabular}{ccccc}
\hline \multirow{2}{*}{ Equations } & \multicolumn{2}{c}{ Coefficient } & \multicolumn{2}{c}{ Multicollinearity Test } \\
& Symbol & Value & Predictor & VIF \\
\hline \multirow{2}{*}{$\operatorname{cog}(T A G B)=\mathrm{c}+\alpha \log (D B H)+\beta \log (W D)$} & $\alpha$ & -0.267 & $\log (D B H)$ & 1.6 \\
& $\beta$ & 0.649 & $\log (W D)$ & 1.6 \\
\hline \multirow{2}{*}{$T A G B=\mathrm{c}+\alpha D B H+\beta W D^{2}$} & $\mathrm{c}$ & -557 & $D B H$ & - \\
\hline & $\alpha$ & 42.4 & $W D^{2}$ & 1.4 \\
& $\beta$ & 540 & & - \\
\hline
\end{tabular}



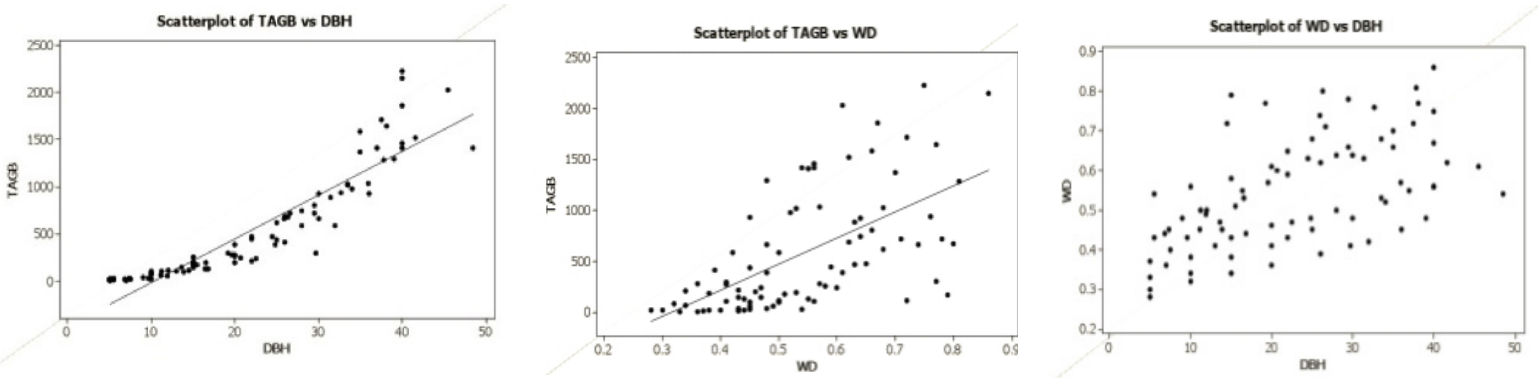

Figure 3. Scatter plots for output-input (TAGB vs $D B H$; TAGB vs $W D$ ) and input-input (WD vs $D B H)$ correlations

Table 4. Pearson's correlation of coefficient for output-input variables

\begin{tabular}{clllr}
\hline \multicolumn{1}{c}{ Equations } & Output $(\mathrm{y})$ & \multicolumn{1}{c}{ Input $(\mathrm{x})$} & $r^{*}$ & \multicolumn{1}{c}{$P$ value } \\
\hline \multirow{2}{*}{$\log (T A G B)=\mathrm{c}+\alpha \log (D B H)+\beta \log (W \mathrm{D})$} & $\log (T A G B)$ & $\log (D B H)$ & 0.97 & $<0.001$ \\
& $\log (T A G B)$ & $\log (W D)$ & 0.68 & $<0.001$ \\
\hline \multirow{2}{*}{$T A G B=\mathrm{c}+\alpha D B H+\beta W \mathrm{D}^{2}$} & $T A G B$ & $D B H$ & 0.91 & $<0.001$ \\
& $T A G B$ & $W D^{2}$ & 0.60 & $<0.001$ \\
\hline \multirow{2}{*}{$T A G B=\mathrm{c}+\alpha W D+\beta D B H^{2}$} & $T A G B$ & $W D$ & 0.61 & $<0.001$ \\
& $T A G B$ & $D B H^{2}$ & 0.94 & $<0.001$ \\
\hline
\end{tabular}

*Pearson's correlation of coefficient

in agreement with studies by Chaturvedi and Raghubanshi (2015) as well as Hunter (2015) that describe the important use of $D B H$ and $W D$ as input variables. Moreover, based on the value of $\mathrm{r}$ in the table, it appears that $T A G B$ has more direct relationship with $D B H(r>0.9)$ than $W D(0.6<r<0.7)$.

Furthermore, in Table 3 normal distribution of residual test was conducted for each established local equation. The result of this test is shown in Figure 4. It illustrates that the residual points for each equation fall near to a straight line in the normal probability plot. As explained by Fahrmeir et al. (2013), this indicates that errors during observation have been normally distributed in every $x$-value and expresses the validity of the normality of the residual assumption.

The final phase of the evaluation for regression assumptions conducted in this study was testing the constant variance of residuals. This evaluation was crucial to make sure that error terms or 'residuals' were constant, and had a mean close to zero. In this study, this test was conducted based on residuals versus fitted values. The result of this test is depicted in Figure 5. Based on this graphical illustration, it can clearly be seen that only the log-based model $(\log T A G B=-0.267+2.23 \log D B H$ $+0.649 \log W D)$ produces valid result to fulfill the assumption of constant variance of residuals. Points on the plot for this log-based model appear to be randomly scattered all over the zero line. Thus, it is highly reasonable to assume that the residuals may have a nearly zero mean and it is virtually constant (Gardner \& Urban, 2003; Fahrmeir et al., 2013).

In contrast, there were noticeable U-shaped patterns for two other non log-based equations, namely $T A G B=-557+42.4 D B H+540 W^{2}$, and $T A G B=-387+710 W D+0.981 \mathrm{DBH}^{2}$. Points of residuals for these two equations were scattered on the positive sides with large 

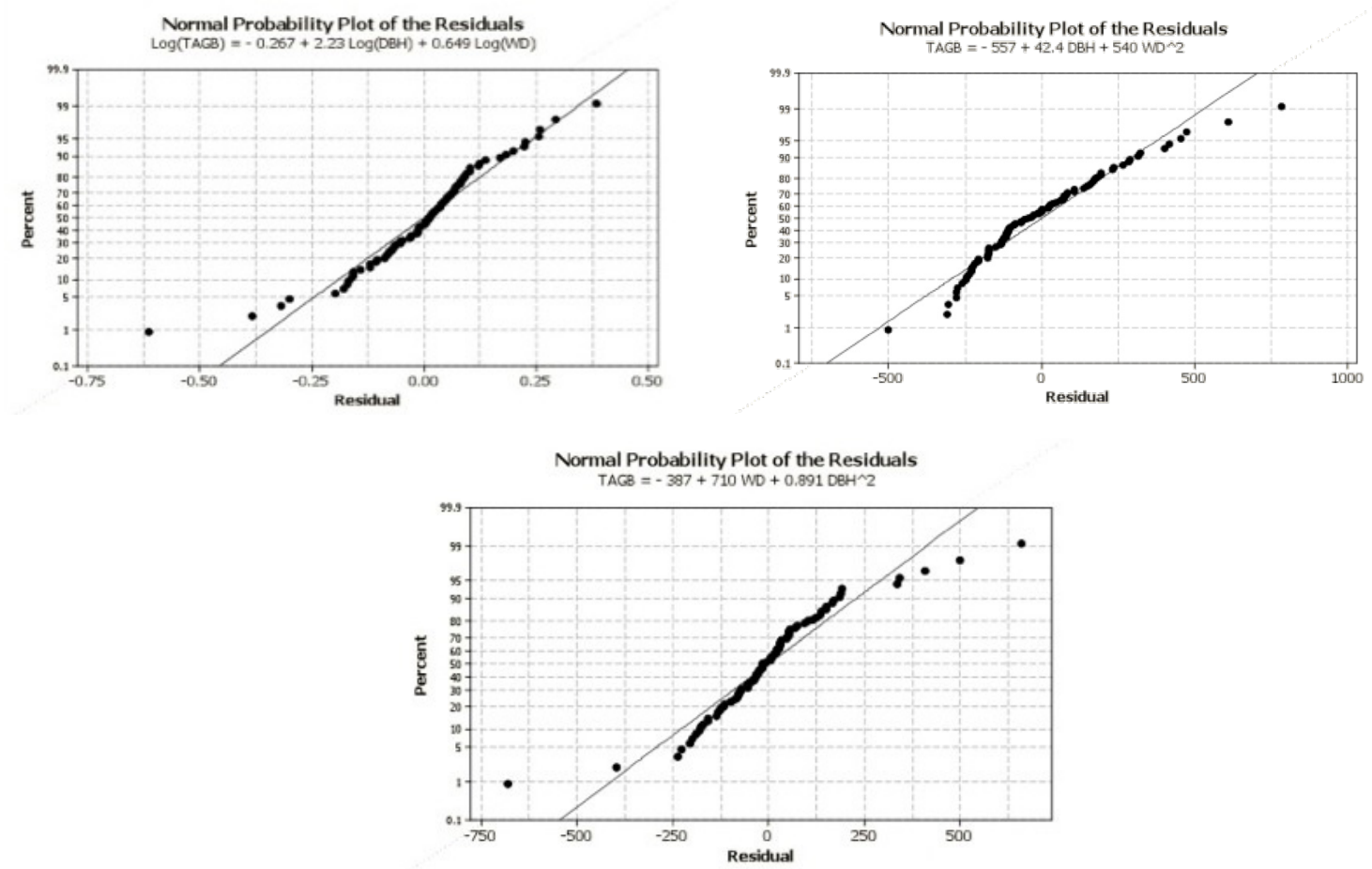

Figure 4. Normal probability plots of the residuals for each equation
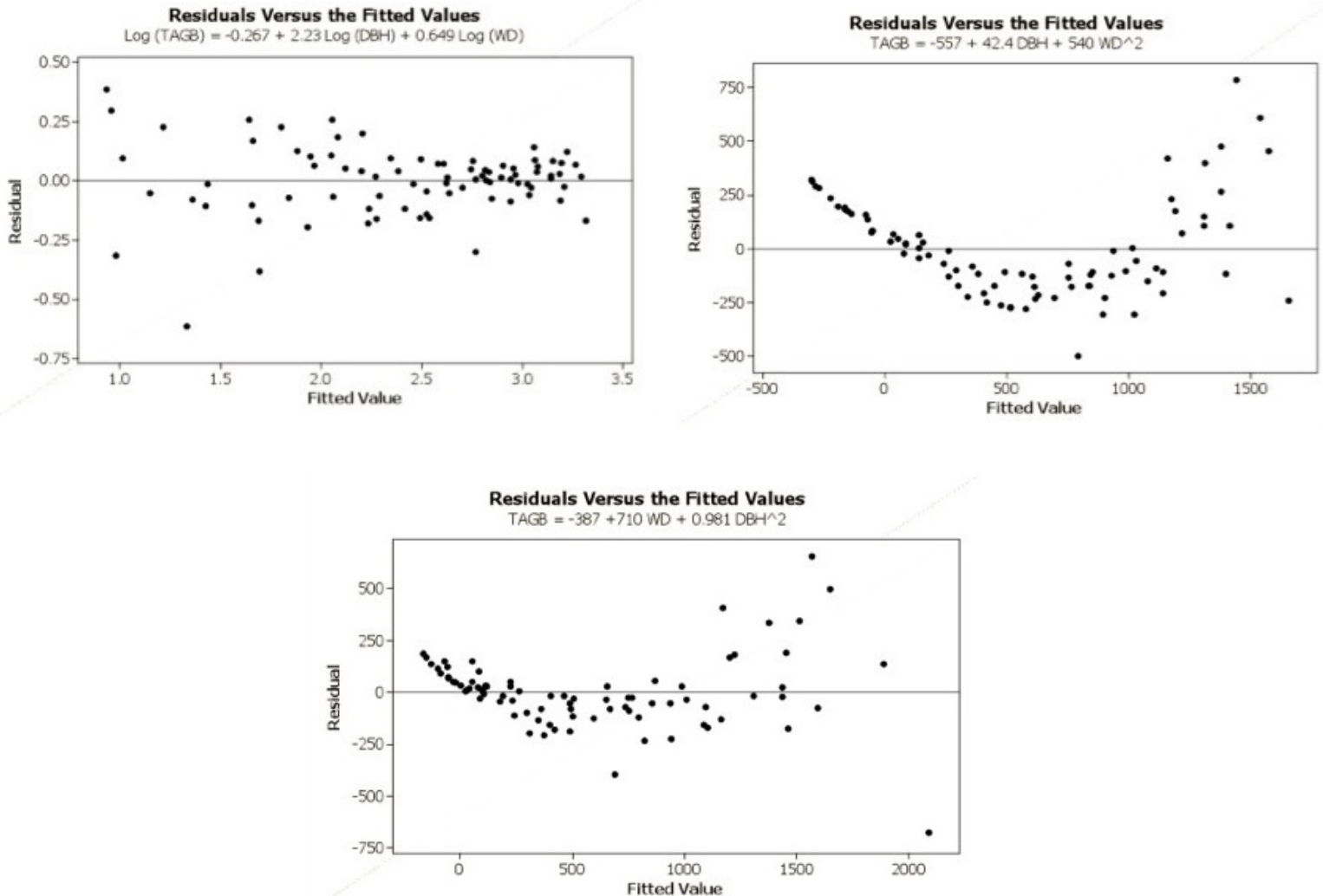

Figure 5. Results of constant variance of residuals test on three developed equations 
Table 5. Evaluation of established local equation

\begin{tabular}{|c|c|c|c|c|c|c|c|c|}
\hline \multirow{2}{*}{ Equations } & \multicolumn{2}{|c|}{ Coefficient } & \multirow{2}{*}{$\begin{array}{c}\text { Standard } \\
\text { error of the } \\
\text { coefficient }\end{array}$} & \multirow{2}{*}{$T$-stat } & \multirow{2}{*}{$\begin{array}{c}R^{2} \\
(\%)\end{array}$} & \multirow{2}{*}{$\begin{array}{l}R^{2} \text {-adj } \\
(\%)\end{array}$} & \multirow{2}{*}{ RMSE } & \multirow{2}{*}{$P$ value } \\
\hline & Symbol & Value & & & & & & \\
\hline \multirow{3}{*}{$\begin{array}{l}\log (T A G B)=c+\alpha \log (D B H)+ \\
\beta \log (W D)\end{array}$} & c & -0.267 & 0.14 & -1.89 & \multirow{3}{*}{95.1} & \multirow{3}{*}{95} & \multirow{3}{*}{0.149} & \multirow{3}{*}{$<0.001$} \\
\hline & $\alpha$ & 2.23 & 0.078 & 28.35 & & & & \\
\hline & $\beta$ & 0.649 & 0.186 & 3.49 & & & & \\
\hline \multirow{3}{*}{$T A G B=c+\alpha W D+\beta D B H^{2}$} & c & -387 & 81.53 & -4.75 & \multirow{3}{*}{91} & \multirow{3}{*}{90.8} & \multirow{3}{*}{178.64} & \multirow{3}{*}{$<0.001$} \\
\hline & $\alpha$ & 710 & 165.1 & 4.3 & & & & \\
\hline & $\beta$ & 0.891 & 0.04 & 21.94 & & & & \\
\hline \multirow{3}{*}{$T A G B=\mathrm{c}+\alpha D B H+\beta W D^{2}$} & c & -557 & 62.44 & -8.91 & \multirow{3}{*}{85} & \multirow{3}{*}{84.6} & \multirow{3}{*}{230.31} & \multirow{3}{*}{$<0.001$} \\
\hline & $\alpha$ & 42.4 & 2.609 & 16.25 & & & & \\
\hline & $\beta$ & 540 & 191.8 & 2.82 & & & & \\
\hline
\end{tabular}

or small fitted values, while holding negative values in the middle. This pattern implies that residuals were less likely to be consistently scattered around the zero line from left to right. Hence, the consistency of the variance of the residuals for both of the non log-based models might become questionable.

Having evaluated the assumptions of regression for each established equation, it seems that the most appropriate model to estimate total aboveground biomass in Papua tropical forest is $\log (T A G B)=-0.267+2.23$ $\log (D B H)+0.649 \log (W D)$ since it produces complete valid results for all given assumption tests. Besides, as shown in Table 5, this logbased equation has the highest coefficient of determination (R-sq) with about 95\%, meaning that it enables to explain up to $95 \%$ of the variability of data response around its mean. This model also has the lowest value of standard error of the coefficient and RMSE. Additionally, this selected log-based model was also completed with its corresponding correction factor for back transforming the model. Correction factor $(\mathrm{CF})$ for the selected log-based model in this study is 1.013 . To the extent of greater accuracy, final estimation result obtained from this model should be multiplied with the correction factor.

\section{B. Pantropical vs Local Equation}

Following the selection of locally developed equation, the selected equation $\log (T A G B)=$ $-0.267+2.23 \log (D B H)+0.649 \log (W D)$ was then compared to two pantropical equations by Chave et al., (2005) namely TAGB $=W D \exp [\mathrm{c}+\alpha$ $\left.\operatorname{Ln}(D B H)+\beta(\operatorname{Ln}(D B H))^{2}+\mathrm{d}(\operatorname{Ln}(D B H))^{3}\right]$ for moist type forest and $T A G B=W D \exp [\mathrm{c}+\alpha$ $\left.\operatorname{Ln}(D B H)+\beta(\operatorname{Ln}(D B H))^{2}+\mathrm{d}(\operatorname{Ln}(D B H))^{3}\right]$ for wet type forest, and an improved model by Chave et al., (2014), which is TAGB $=0.0673 \mathrm{x}$ $D B H^{2} \times$ WD $\left.\times H\right)^{0.976}$. Compared to the actual biomass data that was calculated directly at the research site based on destructive sampling and field weighing of mixed genus trees with the $D B H$ range as covered in the model of this study, it seems that the local model has the lowest value of average deviation and relative bias, with only $6.47 \%$ and 5.37 points respectively. On the other hand, both Chave et al. (2005) and Chave et al. (2014) equations have more than $15 \%$ average deviation and 10 points of relative bias. Furthermore, in order to make it clear, Figure 6 shows a graphical illustration on the comparison of the results of the estimations from each equation with the actual biomass data. 
Table 6. Evaluation against pantropical equations harnessing actual measurements data

\begin{tabular}{|c|c|c|c|c|c|}
\hline \multirow{2}{*}{ Reference } & \multirow{2}{*}{ Equations } & \multicolumn{2}{|c|}{ Coefficient } & \multirow{2}{*}{$\begin{array}{l}\text { Average } \\
\text { deviation }\end{array}$} & \multirow{2}{*}{$\begin{array}{l}\text { Relative } \\
\text { bias } \\
(+/-)\end{array}$} \\
\hline & & Symbol & Value & & \\
\hline \multirow{3}{*}{$\begin{array}{l}\text { Chosen equation of } \\
\text { this study }\end{array}$} & \multirow{3}{*}{$\log (T A G B)=c+\alpha \log (D B H)+\beta \log (W D)$} & c & -0.267 & \multirow{3}{*}{$6.47 \%$} & \multirow{3}{*}{5.37} \\
\hline & & $\alpha$ & 2.23 & & \\
\hline & & $\beta$ & 0.649 & & \\
\hline \multirow{4}{*}{$\begin{array}{l}\text { Chave et al. (2005); } \\
\text { pantropical allometric } \\
\text { for moist type forest }\end{array}$} & \multirow{4}{*}{$T A G B=W D \exp \left[\mathrm{c}+\alpha \operatorname{Ln}(D B H)+\beta\left(\operatorname{Ln}(D B H)^{2}+\mathrm{d}(\operatorname{Ln}(D B H))^{3}\right]\right.$} & c & -1.499 & \multirow{4}{*}{$16.22 \%$} & \multirow{4}{*}{-13.46} \\
\hline & & $\alpha$ & 2.148 & & \\
\hline & & $\beta$ & 0.207 & & \\
\hline & & $\mathrm{d}$ & -0.0281 & & \\
\hline \multirow{4}{*}{$\begin{array}{l}\text { Chave et al. (2005); } \\
\text { pantropical allometric } \\
\text { for wet type forest }\end{array}$} & \multirow{4}{*}{$\begin{array}{l}T A G B=W D \exp [\mathrm{c}+\alpha \\
\left.\operatorname{Ln}(D B H)+\beta(\operatorname{Ln}(D B H))^{2}+\mathrm{d}(\operatorname{Ln}(D B H))^{3}\right]\end{array}$} & c & -1.239 & \multirow{4}{*}{$34.63 \%$} & \multirow{4}{*}{-28.74} \\
\hline & & $\alpha$ & 1.98 & & \\
\hline & & $\beta$ & 0.207 & & \\
\hline & & d & -0.0281 & & \\
\hline \multirow{3}{*}{$\begin{array}{l}\text { Chave et al. (2014); } \\
\text { improved pantropical } \\
\text { allometric }\end{array}$} & \multirow{3}{*}{$T A G B=\mathrm{c} \times\left(D B H^{2} \times W D \times H\right)^{\alpha}$} & c & 0.0673 & \multirow{3}{*}{$15.27 \%$} & \multirow{3}{*}{-12.67} \\
\hline & & & & & \\
\hline & & $\alpha$ & 0.976 & & \\
\hline
\end{tabular}

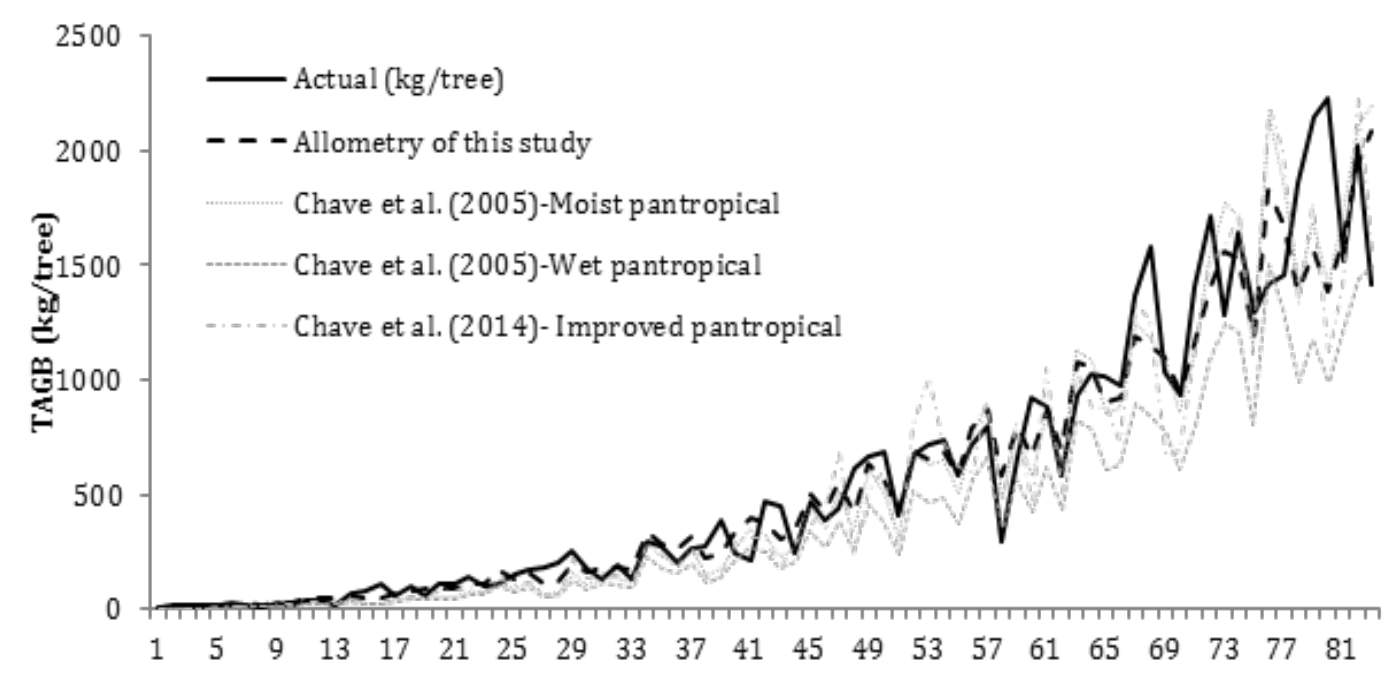

Figure 6. Comparison between actual biomass data and estimate values for each equation

\section{CONCLUSION}

This study highlighted that the most appropriate local model to estimate total aboveground biomass in Papua tropical forest is $\log (T A G B)=-0.267+2.23 \log (D B H)+0.649$ $\log (W D) \quad(C F=1.013 ; \quad V I F=1.6 ; \quad \mathrm{R} 2=95 \%$; R2-adj= 95.1\%; RMSE $=0.149 ; \quad P<0.001)$. In addition, this model is also a better option compared to Chave et al. (2005) and Chave et al. (2014)'s improved pantropical equations with only $6.47 \%$ average deviation and 5.37 points of relative bias in estimating TAGB in Papua Island. This finding implies that the locally developed equation should be considered as a better option to produce more accurate sitespecific total aboveground biomass estimation. 


\section{ACKNOWLEDGEMENT}

We are grateful to the Forestry Research Institute of Manokwari for providing financial support to conduct this research. Thanks are also due to PT. Mamberamo Alas Mandiri in Mamberamo Regency, PT. Arfak Indra in Fakfak Regency, PT. Batasa in Keerom Regency, PT. Manokwari Mandiri Lestari in Teluk Bintuni Regency and head of Waijan Village in Raja Ampat Regency for providing us with the necessary resources and support during the field work. We would like to also appreciate our researchers Mr. Jarot Pandu Panji Asmoro and Mr. Iga Nurapriyanto, as well as our technicians Mr. Frandon Itlay, Mr. Zeth Luther Rumawak, and Mr. Ette Panus for assisting us in the field and laboratory measurements.

\section{REFERENCES}

Achmad, E., Jaya, I. N. S., Saleh, M. B., \& Kuncahyo, B. (2013). Biomass estimation using ALOS PALSAR for identification of lowland forest transition ecosystem in Jambi Province. Jurnal Manajemen Hutan Tropika (Journal of Tropical Forest Management), 19(2), 145-155. http://doi. org/10.7226/jtfm.19.2.145

Alvarez, E., Duque, A., Saldarriaga, J., Cabrera, K., de las Salas, G., del Valle, I., ... Rodríguez, L. (2012). Tree above-ground biomass allometries for carbon stocks estimation in the natural forests of Colombia. Forest Ecology and Management, 267, 297-308. http://doi. org $/ 10.1016 / j$.foreco.2011.12.013

Basuki, T. M., van Laake, P. E., Skidmore, A. K., \& Hussin, Y. A. (2009). Allometric equations for estimating the above-ground biomass in tropical lowland Dipterocarp forests. Forest Ecology and Management, 257(8), 1684-1694. http://doi.org/10.1016/j.foreco.2009.01.027

Chaturvedi, R., \& Raghubanshi, A. S. (2015). Allometric models for accurate estimation of aboveground biomass of teak in tropical dry forests of India. Forest Science, 61(09), 938-949.

Chave, J., Andalo, C., Brown, S., Cairns, M. A., Chambers, J. Q., Eamus, D., ... Yamakura, T. (2005). Tree allometry and improved estimation of carbon stocks and balance in tropical forests. Oecologia, 145(1), 87-99. http://doi.org/10.1007/s00442-005-0100-x

Chave, J., Réjou-Méchain, M., Búrquez, A., Chidumayo, E., Colgan, M. S., Delitti, W. B. C., ... Vieilledent, G. (2014). Improved allometric models to estimate the aboveground biomass of tropical trees. Global Change Biology, 20(10), 3177-3190. http://doi.org/10.1111/ gcb.12629

Clark, D. B., \& Kellner, J. R. (2012). Tropical forest biomass estimation and the fallacy of misplaced concreteness. Journal of Vegetation Science, 23(6), 1191-1196. http://doi. org/10.1111/j.1654-1103.2012.01471.x

De Gier, A. (2003). A new approach to woody biomass assessment in woodlands and shrublands. In P. Roy (Ed.), Geoinformatics for Tropical Ecosystems (pp. 161-198). Dehradun, India: Bishen Singh Mahendra Pal Singh.

Eggleston, S., Buendia, L., Miwa, K., Ngara, T., \& Tanabe, K. (Eds.). (2006). IPCC Guidelines for National Greehouse Gas Inventories, vol. 4: Agriculture, Forestry and Other Land Use. Hayama, Japan: Institute for Global Environmental Strategies (IGES) on behalf of the Intergovernmental Panel on Climate Change (IPCC).

Fahrmeir, L., Kneib, T., Lang, S., \& Marx, B. (2013). Regression: models, methods and applications. Berlin, Germany: Springer.

Fayolle, A., Doucet, J.-L., Gillet, J.-F., Bourland, N., \& Lejeune, P. (2013). Tree allometry in Central Africa: Testing the validity of pantropical multi-species allometric equations for estimating biomass and carbon stocks. Forest Ecology and Management, 305, 29-37.

FWI. (2004). Papua forestry map. Retrieved September 22, 2016, from http://papuaweb. $\mathrm{org} / \mathrm{gb} / \mathrm{peta} /$ fwi/

Gardner, R.H., \& Urban, D.L. (2003). Model validation and testing: past lessons, present concerns, future prospects. In C. D. Ganham, J. J. Cole, \& W. K. Lauenroth (Eds.), Models in Ecosystem Science. Princeton, New Jersey: Princeton University Press.

Henry, M., Besnard, A., Asante, W.A., Eshun, J., Adu-Bredu, S., Valentini, R., ... Saint-André, L. (2010). Wood density, phytomass variations within and among trees, and allometric equations in a tropical rainforest of Africa. Forest Ecology and Management, 260(8), 13751388. 
Hunter, J. T. (2015). Changes in allometric attributes and biomass of forests and woodlands across an altitudinal and rainfall gradient: What are the implications of increasing seasonality due to anthropogenic climate change? International Journal of Ecology, 2015.

Jaya, I. N. S., Agustina, T. L., Saleh, M. B., Shimada, M., Kleinn, C., \& Fehrmann, L. (2012). Above ground biomass estimation of dry land tropical forest using ALOS PALSAR in Central Kalimantan, Indonesia. In Proceeding of The $3^{\text {rd }}$ DAAD Workshop on: Forest in Climate Change Research and Policy: The Role of the Forest Management and Conservation in Complex International Setting (pp. 1-19). Dubai, UAE: DAAD.

Ketterings, Q.M., Coe, R., Noordwijk, M. Van, Ambagau, Y., \& Palm, C. A. (2001). Reducing uncertainty in the use of allometric biomass equations for predicting above-ground tree biomass in mixed secondary forests. Forest Ecology and Management, 146, 199-209.

Lewis, S. L., Lopez-Gonzalez, G., Sonké, B., AffumBaffoe, K., Baker, T. R., Ojo, L. O., ... Wöll, H. (2009). Increasing carbon storage in intact African tropical forests. Nature, 457(7332), 1003-1006.

Lewis, S.L., Sonke, B., Sunderland, T., Begne, S. K., Lopez-Gonzalez, G., van der Heijden, G.M.F., ... Zemagho, L. (2013). Aboveground biomass and structure of 260 African tropical forests. Philosophical Transactions of the Royal Society B: Biological Sciences, 368(1625), 20120295-20120295. http://doi. org $/ 10.1098 /$ rstb.2012.0295

Lima, A. J. N., Suwa, R., de Mello Ribeiro, G. H. P., Kajimoto, T., dos Santos, J., da Silva, R. P., .. Higuchi, N. (2012). Allometric models for estimating above- and below-ground biomass in Amazonian forests at São Gabriel da Cachoeira in the upper Rio Negro, Brazil. Forest Ecology and Management, 277, 163 172. doi:10.1016/j.foreco.2012.04.028
Maulana, S.I. (2014). Allometric equations for estimating aboveground biomass in Papua tropical forests. Indonesian Journal of Forestry Research, 2(1), 77-88.

Nelson, B.W., Mesquita, R., Pereira, J.L.G., De, S.G.A., Teixeira, G., \& Bovino, L. (1999). Allometric regressions for improved estimate of secondary forest biomass in the central Amazon. Forest Ecology and Management, 117, 149-167.

Ngomanda, A., Laurier, N., Obiang, E., Lebamba, J., Moundounga, Q., Gomat, H., ... Picard, N. (2014). Forest Ecology and Management Site-specific versus pantropical allometric equations: Which option to estimate the biomass of a moist central African forest? Forest Ecology and Management, 312, 1-9.

Nogueira, E. M., Fearnside, P. M., Nelson, B. W., \& França, M. B. (2007). Wood density in forests of Brazil's "arc of deforestation": Implications for biomass and flux of carbon from land-use change in Amazonia. Forest Ecology and Management, 248(3), 119-135. http://doi.org/10.1016/j.foreco.2007.04.047

Sprugel, D.G. (1983). Correcting for bias in logtransformed allometric equations. Ecology. http://doi.org/10.2307/1937343

Stewart, J. L., Dunsdon, A. J., Hellin, J. J., \& Hughes, C.E. (1992). Wood biomass estimation of Central American dry zone species. Oxford, England. Retrieved from http://www.bodley.ox.ac.uk/ users/millsr/isbes/ODLF/TFP26.pdf

Tedeschi, L.O. (2006). Assessment of the adequacy of mathematical models. Agricultural Systems, 89(2-3), 225-247. http://doi.org/10.1016/j. agsy.2005.11.004

Vieilledent, G., Vaudry, R., Andriamanohisoa, S. F.D., Rakotonarivo, O.S., Randrianasolo, H. Z., Razafindrabe, H.N., ... Rasamoelina, M. (2012). A universal approach to estimate biomass and carbon stock in tropical forests using generic allometric models. Ecological Applications, 22(2), 572-583. 